\title{
Folk Tale as a Tool for the Teaching of French Grammar: The Case of L'Araignée Et La Mort
}

\author{
F. O. Asadu \\ DOI: http://dx.doi.org/10.4314/ujah.v14i1.7
}

Abstract

Apart from the use of songs, teaching aids and text books in a French language teaching class, folk tale could be used to teach grammar, composition or any aspect of the French language. It makes for easy understanding of the language and improves the students' fluency in class. Bruno sees it as an alphabet primer where one learns to decode before reading. In folktale, speaking precedes writing and the intellectual abilities of the students develop as they sit quietly and listen to the story. The aim of learning a language, especially a foreign language is to acquire linguistic tools to aid competence \& performance, to manifest sociolinguistic and pragmatic coloration in order to diversify linguistic and cultural repertories. This paper aims at teaching French tale entitled "L'araignée et la mort "in a French class," using Communicative approach to teach Grammar, Composition, Oral Comprehension and Phonetics.

\section{Introduction}

Over the years efforts have been made on the best approach or method to teach French language. The first method was the traditional method which was grammar based. It was criticized because the method could not make students speak fluently. The students learn French by memorizing the lesson which is translation based. 
L1

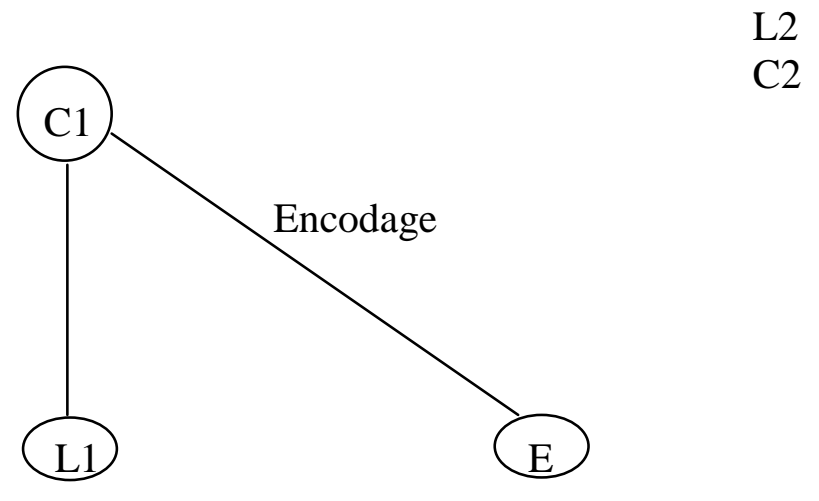

L1- Source language

L2- Target language

C- Concept

E- Expression

The students hear the language understand it, translate it into their mother tongues and then try to repeat it severally in order to speak it.

The second method is the audio-lingual method, which was started in 1950 by B.F. Skinner. It is based on psycholinguistique approach. It discourages the use of teaching aids like real objects, maps etc in a French class, the method involves listing and repeating what one hears since psychologists believe that learning any language starts with the acquisition of the rules. "L'apprentissage d' une langue est avant tout l'acquistion des habitudes".

This method is stimulus- response based.

The direct method followed. In this method, students are prohibited from speaking any other language except French. It was criticized because the teacher is seen as a role 
model and the majority of the students do not understand the lesson.

Audio-visual method afterwards was introduced. The students see and listen to the lesson at same time. It encourages the use of T.V, Video, technicians, but because it is expensive, coupled with the incessant power failure in Nigeria, not many schools could afford afford them for their schools.

The latest method now is the communicative method. This encourages the use the mother tongue in class. It is based on this method that the writer of this paper encourages the use of story telling of any sort to teach French. The linguists have found this aspect of folk tale interesting in the study of linguistics in this regard William said:

Linguistics is somewhat more closely related, both because the style of verbal expression of a tale or proverb is influenced by vocabulary and grammatical structure, and because linguists have found folktales and myths convenient devices for collecting linguistics texts, with the result that some of them more carefully recorded and translated American Indian tales have been published by linguists.

The writer will show how one can use tales to teach language in a French class using the spider and the death. L'araignée et la mort.

\section{What is Folk tale?}

Folktale is one of the three basic terms in folklore. Folklore which in itself is a branch of social or cultural anthropology, concerned with the study of the customs, traditions and institutions of people. William categorizes folktale as one prose narrative, he says: 
Prose narrative, I propose, is appropriate term for the widespread and important category of verbal art, which includes myths, legends and folktales. These three forms are related to each other in that they are narratives in prose, and this fact distinguishes them from proverbs, riddles, ballads, poems, tongue-twisters, and other form of verbal art on the basis of strictly formal characteristic.

The New Webster's Dictionary of the English language defines folktale as "an anonymous traditional story, orally transmitted, the subject rarely being tied to a particular time or place". Oxford Dictionary \& Thesaurus defines it as "popular or tradition story while New English Dictionary \& Thesaurus defines it as "an anonymous, timeless and placeless tale circulated orally among a people."

From these definitions, one can observe that folktale is always a story told in which its place and time could not be traced. It is common among a particular community or ethnic group. Kirszner, Mandel, Fertitile say:

Folktales \& fairy tales also come out of an oral tradition. These tales, which developed along with other narrative form, have influenced works as diverse as Chaucer's the Canterbury tales \& D.H. Laurence's "The Rocking- Horse winner".

The folktales and fairy tales that survive even ancient times are tales that can be traced back centuries through many cultures.

\section{Characteristics of Folk tale}

The characters of these tales are human or animal. According to G.I Achufusi quoted by Ogbe such human characters usually remain indefinite referred to as "a certain man, a certain woman or boy, girl or child". Folktales and fairy tales 
share certain characteristics. First they can be summed up in a few words.

Secondly, the folktale has an obvious theme or moral, good triumphing over evil, for instance, the stories move directly to their conclusion, never interrupted by ingenious or unexpected twists of plot.

Thirdly, these tales are anchored not in specific times or places but in "once upon a time", "Chakpii Woo" settings, green worlds of prehistory filled with royalty, talking animal or magic.

Lastly, it contains some elements of mysticism or magics, transferred from one generation to another, teaching/imparting knowledge, moral and culture of the people.

Examples of animal characters in folktale are:-

$\begin{array}{llll}\text { English } & \text { Igbo } & \text { French } & \text { Gloss } \\ \text { Tortoise } & \text { Mbe } & \text { La torture } & \text { intelligence } \\ \text { Dog } & \text { Nkita } & \text { Le chien } & \text { Security } \\ \text { Chicken } & \text { Nwunye Okuko } & \text { La poule } & \text { Motherhood } \\ \text { Owl } & \text { Ikwikwi } & \text { Le hibou } & \text { Calamity } \\ \text { Sheep } & \text { Aturu } & \text { La chevre } & \text { Stupidity } \\ \text { Snail } & \text { Ejula } & \text { L'escargot } & \text { Sluggishness }\end{array}$

Thus when animals are used in folktales, it means a lot in England, the fox is used in place of tortoise. In other African, francophone countries they use I' araignée to represent intelligence and wisdom. (Hence the title of this paper L'araignée et la mort (spider and death) are used.

\section{Classification of folk tales}

\section{Dilemma tales.}

A dilemma tale is one, which requires the audience to make a choice among many competing alternative during a conflict situation. Dilemma folktales are therefore deductive in nature. They require the audience to be active participants in the discussion by making them to be intellectually alert. As such, 
folk tales make a lot of demand on the intellectual capacity of the audience. This is to say that the audience must exercise their intellectual ability and wit in order to be able to give moral judgment concerning the folktales. The implication is that member of the audience can choose from the available options, what they judge to be the best. An example of this is the story of three friends who said that they were looking for death. One man directed them to a nearby tree where they would find death. On getting to the tree they saw a carton of money. They grabbed it and sent one of them to buy akara. When he came back, the boy in question put poison in the akara in order to kill the other two so that he could take the money alone. In his absence, the other two conspired to kill him when he returns; he gave them the akara and was killed with a stick as planned. Thereafter, they ate the poisoned Akara, and died too. Thus the three boys died leaving the money.

\section{Etiological tales}

Another category of folk tales is the etiological folktales. These folktales are also referred to as why folk tales. This is because they usually explain why certain thing are the way they are, for example, things like the origin of man, nature of the world, why people die, why the tortoise has shell. Example-: all animals were once summoned to a meeting in the sky. Tortoise borrowed feathers from birds and they were given to him. Tortoise flew with them. On getting there, they were each asked to choose a name. Tortoise choosed the name All of you so when they brought food, the person will say all of you and tortoise will finish the food. As a result of that all the animals who donated feathers to it collected them back. Tortoise had to fall from the sky and that is why tortoise's shell has cracks all over. 


\section{Moral tales:}

There are also folktales that teach moral, obedience, justice, fair play kindness, humility, good behavior towards mankind. An example can be cited of a woman who had three daughters and a maid. She over-pampered her daughters by not allowing them to be involved in household chores.

Meanwhile the maid did all, one of them got married and could not cook for her husband, and her husband sent her back to her parents. The maid eventually got married and was cherished by her husband.

\section{Task folktales:}

Another is a task folktale. In task folktales a task that look impossible is set out by a superior being by an inferior being. The superior being in this case mandates the inferior being to complete the impossible task or face severe consequence. One thing about these task folktales is that the inferior being is always able to complete the task usually through the help of supernatural or magical power. Example is the story of Ojadili._According to Ogbe, such an inferior being is able to complete the task through courage, faith, determination and equanimity. Notable among these folklorists are Ruth Finnegan, Rem Nna Umeasiegbu, Romanus Egugdu to mention but a few.

\section{How to Use Folk Tale in a Language Class Using 'L'Araignée Et La Mort'}

Folktale is very important in a French language class. It could be used to teach the following-: grammar, composition, lexis, comprehension, and phonetics.

\section{Grammar}

The teacher can tell the students to bring out the verbs used in this story 'L'araignee et la mort'. After that, the teacher will ask them to write out the following: verbs in infinitive forms, 
verbs used in the past tense and in the present tense respectively.

Example based on 'L'araignée et la mort'

Infinitive verbs-: acheter, chanter, dire, se souvenir, trouver etc.

From these infinitives extracted from the story the teacher can teach the students the following structure in French.

A. Subject + Verb + Infinitive + Nom

Elle veut acheter le bœuf (line 3 paragraph 1)

$\mathrm{Tu}$ peux dire mon nom ( $4^{\text {th }}$ paragraph line 3$)$

Elle va trouver sa femme $\left(4^{\text {th }}\right.$ paragraph line 1$)$

B. Subject + verb + preposition infinitive.

L'araignée essaie de souvenir (paragraph 5 line1)

The teacher can also use this story to teach the grammatical categories of mood. For example he/she will teach them gerund (Le gerondif) as a mood that will always take the preposition en_in French before the present participle, that is, the difference between gerund in French and present participle. From the story "le gerondif" are-: "en allant", "en travaillant" etc. this mode is an example of an impersonal mode in French.

The teacher will tell the student to write out the verbs in the present tense with their infinitives,

\begin{tabular}{l|l} 
Verbs & Infinitives \\
\hline Parcourt & parcourir \\
a & avoir \\
veut & vouloir \\
donne & donner \\
appelle & appeler etc.
\end{tabular}


The teacher will tell the students to underline the articles in the passage e.g.the definite articles "le, la, l', les". Consequently, explains their grammatical function in the language as follows:

La is feminine + singular

Le is masculine + singular

$\mathrm{L}^{\prime}$ is masculine + feminine + vowel or silent $\mathrm{h}+$ singular

Les plural + masculine + feminine + vowel or silent $h$.

The same story could be used by the teacher to teach nouns. He/she will tell the students that we have proper nouns which are names given to individuals, countries, oceans etc. common nouns which are general names given to things and abstract nouns. Example from the passage:

Proper noun:- Wanaberi, L'araignée.

Common nouns:- La boeuf, son fils, la femme etc.

Abstract noun-: La mort

\section{Oral comprehension}

The primary objective of folktale is to understand and reply orally. It is hoped that the teacher will help the students to talk in class using the following questions below-:

1. Qui a très faim?

2. Qu' est-ce qu'il faut acheter?

3. Qui le lui a donné?

4. Qui frappe à la porte de l'araignée

5. Pourquoi?

6. Quelle est la leçon tirée de ce conte?

\section{Composition}

In communicative approach, a learner is free to use his/her mother tongue in a French class. When they have understood the story, the teacher will then tell them to write a similar 
narrative story in their own way. He can ask them whether they have heard about such a story in their place, or whether they have watched it in films or have heard it in the radio. The students will be told to write a similar narrative story using simple sentences. This will give birth to creativity and originality. The students will now discover the hidden capacity in them and know that creativity does not belong to artists or intellectuals. Creativity belongs to every individual young or old, big or small, educated on uneducated. Creativity is like a river that flows in every human being and its diversification is what keeps life going. If not the world would have been monotonous, devoid of variety and originality. This creative inducement can make the students start writing poems, novels, and storybooks right from their primary school.

\section{Intonation}

Intonation is the movement of voice; it could be low or high. In French we have three types of intonation:

L' intonation montante/ the rising tune

L' intonation descendante/ the falling tune

L' intonation plate.

Examples of these intonations from the story are as follows-:

1. Intonation Montante - (The Rising Tone)

Attends un peu!

Qui est-ce?

Est-ce que tu peux dire mon nom?

2. L' intonation descendante (the falling tone)

C' est moi, la mort

Wanakiri, Wanaberi

3. L' intonation plate.

Sa femme pleure. 


\section{Syllable}

In French we have two types of syllables: open and closed syllables. When a word ends in a vowel and that vowel is pronounced, we have open syllable on the contrary, when a word ends in a consonant and that consonant is pronounced we have a closed syllable. About $80 \%$ of French words have open syllables. Examples of Open Syllables from the folktale are-:

Araignée - [a-Re- $\eta$ e] three syllab;les

Faim $\left[\mathrm{f} \sum\right]$ one

Trouver [tru - ve] two

Travaillant [tra - ve-jã] three

Closed Syllables

Mort $\{\mathrm{moR}\}$ one

Femme $\{$ fam $\}$ one

Par court $\{\mathrm{paR}-\mathrm{kuR}\}$ two

\section{Conclusion}

The writer has stressed the importance of folk tale in a language class especially in a foreign language class like French. She opines that folktale should be seen as a technique in communicative method approach in teaching the French language, as this will enhance the speaking skill, mental creativity and writing skill. She has shown how possible this could be by using an example of $\mathbf{L}$ 'araignée et la mort. With this, any tale the students are familiar with will go a long way in making the teaching of French less taskful and very interesting, as the students will be echoing the lecture as it goes on.

Asadu F. O. is of the Department of Modern European Languages, Nnamdi Azikiwe University, Awka 


\section{Bibliography}

Beltelheim, B Psychanalyse des contes de fees Paris: Laffont, 1976.

Françoise Balogun. L'araignée et la mort in Olikperebu et autre contes. Lagos: Ethiope Pub Coop, 1978.

Kirszner, Mandel, Fertile. Literature Reading Reacting and Writing lst edition, Canada, Harcourt collage. 2003.

Nwanjoku,C "Translating, African literature, A case for the translation of igbo tales into English". Journal of new students in languages and literary studies. Uturu, 2005.

Ogbo N.G. Essentials of literature a comprehensive approach to literary appreciation. Enugu gabrace optimal ventures (Nig) 1997.

Skinner B.F. "The science of learning and the art of teaching". Education Reviers .London,havard, 1975.

Williams R.Boscom.Four functions of folklore.The journal of American Folklore, Vol.66 No.262. (Oct-Dec.1954) pp.283-290.

\section{Dictonaries}

The New Webster' Dictionary of the English language; Florida, Trident Press international, 2004.

Oxford Dictionary \$ Thesaurus 11l. New York, Oxford University Press, 2002.

New English Dictionary \$ Thesaurus, New edition, Scotland, geddes \$ grosset, 1994.

\section{Appendix}

\section{L'araignée Et La Mort}

La mort parcourt le pays avec un boeuf très gras. L'araignée a très faim et $n$ ' a rien à manger. Elle veut acheter le boeuf. La mort le lui donne et demande pour seul prix que l'araignée se souvienne de son nom au bout d' un an.

La mort part. L'araignée appelle sa femme et son fils leur apprend le nom de la mort: wanaberi”. Elle leur demande 
de chanter tous les jours en travaillant" wanakiri, "Wanaberi". Ainsi l'araignée croit que elle se souviendra du nom de la mort.

Les mois passent. On chante toujours: Wanakiri, Wanaberi en allant chercher de l'eau et en travaillant.

Mais, peu à peu, on oublie les paroles du chant et lorsque le dernier jour de l' année arrive la mort à la porte de l'araignée.

- Qui est-ce dit celle-ci

- C'est moi, la mort. Est-ce que tu peux dire mon nom?

- Attends un peu.

L'araignée essaie de se souvenir. Elle va trouver sa femme: elle a oublié, elle aussi, le nom de la mort.

La mort, alors emporte l'araginée. Sa femme pleure. Son fils qui arrive des champs, demande ce qui se passe et elle lui dit. Attends! Dit l'enfant. Il monte sur un arbre, aperçoit la mort et crie très fort: Wanakiri, Wanaberi! L'araignée est sauvée et la mort s'en va.

\section{The English Translation of the Folk Tale "The Spider and the Death".}

The death goes round the city like a fattened big cow. The spider is very hungry and has nothing to eat. The spider wants to buy beef. The death gave it to him and asked him to pay a price which is to remember his name within one year.

The death left, the spider called his wife and his son and tells them the name of the death, wanaberi. The spider asked the wife and the son to recite that name everyday while walking. Wanakari, Wanaberi. Also the spider thought that he will remember it.

Months passed. They sing it always while going to fetch water and while walking.

Little, by little, they forgot the lyrics and at the last day of the year, the death came knocking at the door of the spider, who is that? says the spider. 
It is me, the death, can you call my name? wait a minute.

The spider tries to remember it but he could not, he asked the wife, but the wife has also forgotten it.

The death took the spider. His wife started crying. His son that was returning from farm asked the mother what the problem was and she told him.

Wait! says the son. He climbs a tree, sees the death and cried in a loud voice: wanakiri, wanaberi!

The spider was saved and the death left. 